Administration warned of continuing "serious threats to commercial vessels" by Iran and its proxies in the Strait of Hormuz and the Arabian Sea, ${ }^{58}$ causing increased patrols by countries whose industries rely on passage through the strait. ${ }^{59}$ On February 9, while patrolling the area, the United States intercepted Iranian-made weapons destined for the Houthi rebels in Yemen, ${ }^{60}$ who have been fighting a Saudi-led and U.S.-backed coalition since 2015. ${ }^{61}$ In Syria, Iran has continued to back the Syrian government forces, who have engaged in a months-long offensive to retake Idlib, which sits on the Syrian-Turkish border and has been the last rebel-held area. ${ }^{62}$ The United States has condemned the "unjustifiable, and ruthless assaults on the people of Idlib" and reiterated that it "stand[s] by [its] NATO Ally Turkey."63

\title{
United States Creates the U.S. Space Command and the U.S. Space Force to Strengthen Military Capabilities in Space
}

doi:10.1017/ajil.2020.13

President Trump first announced his plans for increasing U.S. military capabilities in space in 2018. In August 2019, his administration created the United States Space Command. With the passage in December 2019 of the 2020 National Defense Authorization Act, the United States established the United States Space Force as a new branch of the armed forces.

Dan Lamothe \& Mustafa Salim, U.S. Counters Iraq's Condemnation of Airstrikes on Iran-Backed Militia Facilities, Wash. PosT (Mar. 13, 2020), at https://www.washingtonpost.com/world/iraq-condemns-us-strikes-on-iranbacked-militias-say-they-killed-soldiers-and-a-civilian/2020/03/13/33650322-6519-11ea-8a8e-5c53 36b32760_story.html.

58 2020-001-Persian Gulf, Strait of Hormuz, Gulf of Oman, Arabian Sea, Red Sea, Gulf of Aden, and Indian Ocean-Threats to Commercial Vessels by Iran and its Proxies, MARAD (Jan. 13, 2020), at https://maritime.dot. gov/content/2020-001-persian-gulf-strait-hormuz-gulf-oman-arabian-sea-red-sea-gulf-aden-and-indian-ocean [perma.cc/G8RS-3S3Z].

${ }^{59}$ Tim Kelly, Japanese Warship Departs for Gulf to Patrol Oil Lifeline, ReUTERS (Feb. 1, 2020), at https://www. reuters.com/article/us-mideast-iran-japan/japanese-warship-departs-for-gulf-to-patrol-oil-lifelineidUSKBN1ZW02D.

${ }^{60}$ See U.S. Central Command Press Release, US Navy Seizes Illegal Weapons in Arabian Sea (Feb. 13, 2020), at https:/www.centcom.mil/MEDIA/PRESS-RELEASES/Press-Release-View/Article/2083824/us-navy-seizesillegal-weapons-in-arabian-sea [perma.cc/6JNF-L6HU] (describing the seizure of weapons resembling those made by Iran); Mike Pompeo (@SecPompeo), TwiTter (Feb, 14, 2020), at https://twitter.com/SecPompeo/status/ 1228285173936140290 [perma.cc/S5MG-54M3] ("The U.S. Navy interdicted 358 Iranian-made missiles + other weapons components on their way to the Houthis in Yemen"); see generally Panel of Experts on Yemen, Final Report of the Panel of Experts on Yemen, Transmitted Letter Dated 27 January 2020 from the Panel of Experts on Yemen Addressed to the President of the Security Council, UN Doc. S/2020/70 (Jan. 27, 2020), at https://undocs.org/s/2020/70 (discussing Iranian support for the Houthis, including potentially illicitly providing weapons).

${ }^{61}$ Claire Parker \& Rick Noack, Iran Has Invested in Allies and Proxies Across the Middle East. Here's Where They Stand After Soleimani's Death, WASH. PosT (Jan. 3, 2020), at https://www.washingtonpost.com/world/2020/01/ 03/iran-has-invested-allies-proxies-across-middle-east-heres-where-they-stand-after-soleimanis-death.

${ }^{62}$ Id.; Adam Taylor, The Idlib Crisis Is a Reminder that the Syrian War Is Not Over, WASH. PosT (Feb. 6, 2020), at https://www.washingtonpost.com/world/2020/02/06/idlib-crisis-is-reminder-that-syrian-war-is-not-over.

${ }^{63}$ Mike Pompeo, Sec'y of State Press Release, Escalation of Violence in Idlib (Feb. 4, 2020), at https://www. state.gov/escalation-of-violence-in-idlib [perma.cc/UZ49-JXMB]. 
These developments do not directly implicate international law, but they reflect a growing divergence between the U.S. approach to space and that taken by the UN General Assembly. In June 2018, Trump publicly announced his intention to establish "'American dominance in space" "through the creation of a Space Force. ${ }^{1}$ His announcement came after the release of the "Worldwide Threat Assessment of the US Intelligence Community," which warned of China and Russia's capacity to "offset any perceived US military advantage derived from military, civil, or commercial space systems" through their antisatellite weapons, should the United States engage in military confrontation with the two countries. ${ }^{2}$ A year later, on August 29, 2019, the Pentagon established the U.S. Space Command as a new geographic combatant command. ${ }^{3}$ The U.S. Space Command is authorized to employ assigned forces from the various military service branches to achieve its mission "to deter aggression and conflict, defend U.S. and allied freedom of action, deliver space combat power for the Joint/Combined force, and develop joint warfighters to advance U.S. and allied interests in, from, and through the space domain." 4

During the preparations for the negotiations between the White House and Congress over the 2020 National Defense Authorization Act (2020 NDAA), Trump reportedly instructed White House negotiators to make the creation of the Space Force their most important priority. ${ }^{5}$ As a military service branch focused on space, the Space Force would complement the

${ }^{1}$ Jean Galbraith, Contemporary Practice of the United States, 113 AJIL 634, 638 (2019) (quoting Associated Press, Trump Announces Creation of Space Force, YouTube (June 18, 2018), at https://www.youtube.com/watch? $\mathrm{v}=\mathrm{Kna3YYX7XeE).} \mathrm{A} \mathrm{Space} \mathrm{Command} \mathrm{had} \mathrm{previously} \mathrm{existed} \mathrm{within} \mathrm{the} \mathrm{U.S.} \mathrm{military} \mathrm{from} \mathrm{1985-2002.} \mathrm{Id.} \mathrm{at}$ 638 n. 24.

${ }^{2}$ Daniel R. Coats, Director of National Intelligence, Statement for the Record, Worldwide Threat Assessment of the US Intelligence Community 13 (2018), available at https://www.dni.gov/files/documents/Newsroom/ Testimonies/2018-ATA_Unclassified-SSCI.pdf [https://perma.cc/2PGY-ANKM].

${ }^{3}$ U.S. Space Command Press Release, United States Space Command Fact Sheet (Aug. 29, 2019), at https:// www.spacecom.mil/About/Fact-Sheets-Editor/Article/1948216/united-states-space-command-fact-sheet [https://perma.cc/U36G-YJHM]; U.S. Dep't of Defense Press Release, Jim Garamone, Pentagon Rolls Out Space Command (Aug. 29, 2019), at https://www.defense.gov/Explore/News/Article/Article/1948420/pentagon-rollsout-space-command [https://perma.cc/3P7L-HZU5]. A Combatant Command is "a military command which has broad, continuing missions and which is composed of forces from two or more military departments." 10 U.S.C. \$161(c)(1) (2018). Currently, there are eleven Combatant Commands, of which six are geographic commands and five are functional commands. Kathleen J. McInnis, Cong. Research Serv., IF10542, Defense Primer: Commanding U.S. Military Operations 2 (2020). The three military departments are the Department of the Army, the Department of the Navy, and the Department of the Air Force. Heidi M. Peters, Cong. Research Serv., IF10550, Defense Primer: The Military Departments 1 (2018). The decision to establish the Space Command as a full Combatant Command, as distinct from a sub-unified command within a preexisting Combatant Command, was in tension with a prior congressional statute. See Galbraith, supra note 1, at 639. This prior statute was repealed in December of 2019, several months after the establishment of the Space Command. National Defense Authorization Act for Fiscal Year 2020, Pub. L. No. 116-92, \$1601, 133 Stat. 1198 (2019) [hereinafter 2020 NDAA].

${ }^{4}$ United States Space Command Fact Sheet, supra note 3. The military service branches, also known as the armed forces, refer to the Army, the Navy, the Air Force, the Marine Corps, the Coast Guard, and, most recently, the Space Force. See U.S. Dep't of Defense Press Release, Department of Defense Establishes U.S. Space Force (Dec. 20, 2019), at https:/www.defense.gov/Newsroom/Releases/Release/Article/2045981/department-ofdefense-establishes-us-space-force [https://perma.cc/SMC3-7G27] [hereinafter DOD Press Release] (noting "the establishment of the U.S. Space Force as the sixth branch of the armed forces"); PETERS, supra note 3 (listing the branches of the armed forces).

${ }^{5}$ Jeff Stein, Lisa Rein \& Josh Dawsey, Democrats Leveraged Trump's Fixation on Space Force to Pursue ParentalLeave Victory for Federal Workers, WASH. PosT (Dec. 8, 2019), at https://www.washingtonpost.com/business/ economy/democrats-leveraged-trumps-fixation-on-space-force-to-pursue-parental-leave-victory-for-federalworkers/2019/12/08/92f290fc-19ce-11ea-826b-14ef38a0f45f_story.html. 
mission-focused Space Command. To secure Democratic support for the creation of the Space Force, the White House conceded to the inclusion of a provision for twelve-week paid parental leave for civilian federal employees. ${ }^{6}$ Trump signed the 2020 NDAA into law on December 20, 2019,7 thus establishing the United States Space Force (USSF) within the Department of the Air Force. ${ }^{8}$

The USSF is headquartered in the Pentagon and is the sixth branch of the armed forces. ${ }^{9}$ According to the USSF's mission statement:

The USSF is a military service that organizes, trains, and equips space forces in order to protect U.S. and allied interests in space and to provide space capabilities to the joint force. USSF responsibilities include developing military professionals, acquiring military space systems, maturing the military doctrine for space power, and organizing space forces to present to [the] Combatant Commands. ${ }^{10}$

As the USSF is situated within the Department of the Air Force, the secretary of the air force-overseen by the secretary of defense-is responsible for the USSF. ${ }^{11}$ In turn, the chief of space operations, a four-star general and a full member of the Joint Chiefs of Staff, serves as the "principal uniformed advisor to the Secretary of the Air Force on Space Force activities."12

The United States is party to the Outer Space Treaty, which obligates states to "carry on activities in the exploration and use of outer space . . . in accordance with international law, including the Charter of the United Nations, in the interest of maintaining international peace and security." 13 The treaty bars the "place[ment] in orbit around the earth [of] any objects carrying nuclear weapons or any other kinds of weapons of mass destruction" and limits the use of the "moon and other celestial bodies" to "exclusively. . p peaceful purposes." 14

While the creation of the U.S. Space Command and the USSF does not directly implicate international law, it does raise questions about future U.S. activities in space and about the compatibility of these activities with international law. General Mark A. Milley, chairman of the Joint Chiefs of Staff, stated that space is of strategic military importance because it supplements combat operations on Earth, but it is also a "warfighting domain in and of itself." 15

\footnotetext{
${ }^{6}$ Catie Edmondson, House Passes $\$ 738$ Billion Military Bill with Space Force and Parental Leave, N.Y. TIMES (Dec. 17, 2019), at https://www.nytimes.com/2019/12/11/us/politics/house-ndaa-space-force-leave.html; 2020 NDAA, supra note 3, $\$ 7602$.

${ }^{7}$ Donald J. Trump, Remarks on Signing the National Defense Authorization Act for Fiscal Year 2020 at Joint Base Andrews, Maryland, 2019 Daily Comp. Pres. Doc. No. 885, at 3 (Dec. 20).

${ }^{8} 2020$ NDAA, supra note 3, \$952. The 2020 NDAA passed in the House 377 to 48.165 Cong. Rec. H10092 (daily ed. Dec. 11, 2019) (Roll No. 672). In the Senate, it passed 86 to 8.165 ConG. ReC. S7070 (daily ed. Dec. 17, 2019) (Vote No. 400).

${ }^{9}$ DOD Press Release, supra note 4; U.S. Space Force Press Release, U.S. Space Force Fact Sheet (Dec. 20, 2019), at https://www.spaceforce.mil/About-Us/Fact-Sheet [https://perma.cc/86MT-S5VW].

${ }^{10}$ U.S. Space Force Fact Sheet, supra note 9.

${ }^{11} I d$.

${ }^{12}$ Id.; see also 2020 NDAA, supra note 3, $\$ 953$ (establishing this position and defining its scope).

${ }^{13}$ Treaty on Principles Governing the Activities of States in the Exploration and Use of Outer Space, Including the Moon and Other Celestial Bodies, Art. 3, Jan. 27, 1967, 18 UST 2410, 610 UNTS 205.

${ }^{14}$ Id. Art. 4 (specifically proscribing the "establishment of military bases, installations and fortifications, the testing of any type of weapons and the conduct of military maneuvers on celestial bodies").

${ }^{15}$ DOD Press Release, supra note 4.
} 
The mission of the U.S. Space Command reflects Milley's attitude-one of the U.S. Space Command's focus areas is that it "will improve the development of joint space operations forces and capabilities to enhance space warfighting readiness and lethality while accelerating the integration of space capabilities into other warfighting forces." 16 Similarly, the duties of the USSF are to "deter aggression in, from, and to space" and "conduct space operations."17 These developments contrast with recent actions taken at the United Nations, where five resolutions were adopted at the seventy-fourth session of the General Assembly addressing the issue of the prevention of an outer space arms race. ${ }^{18}$

${ }^{16}$ United States Space Command Fact Sheet, supra note 3.

${ }^{17}$ NDAA 2020, supra note $3, \$ 952$.

${ }^{18}$ The five resolutions the General Assembly adopted were on "further practical measures for the prevention of an arms race in outer space," GA Res. 74/34 (Dec. 12, 2019); "international cooperation in the peaceful uses of outer space," GA Res. 74/82 (Dec. 12, 2019); "no first placement of weapons in outer space," GA Res. 74/33 (Dec. 12, 2019); "prevention of an arms race in outer space," GA Res. 74/32 (Dec. 12, 2019); and "transparency and confidence-building measures in outer space activities," GA Res. 74/67 (Dec. 12, 2019). The United States voted against all of these resolutions except the one on international cooperation, which was adopted by consensus. 